\title{
Cultivation and identification of blazeispirols of Agaricus campestroides and $A$. flocculosipes
}

\author{
Chuankid B $\mathrm{B}^{1,2,3,5}$, Schrey $\mathrm{H}^{3,4}$, Stadler $\mathrm{M}^{3,4}$, Thongklang $\mathrm{N}^{1,2}$, Hyde $\mathrm{KD}^{1,2^{*}}$ \\ ${ }^{1}$ Center of Excellence in Fungal Research, Mae Fah Luang University, Chiang Rai 57100, Thailand \\ ${ }^{2}$ School of Science, Mae Fah Luang University, Chiang Rai 57100, Thailand \\ ${ }^{3}$ Department of Microbial Drugs, Helmholtz Centre for Infection Research, Inhoffenstraße 7, 38124 Braunschweig, \\ Germany \\ ${ }^{4}$ Technische Universität Braunschweig, Institute for Microbiology, 38106 Braunschweig, Germany \\ ${ }^{5}$ Rak Ruay Mushroom Farm, Phetchabun 67160, Thailand
}

Chuankid B, Schrey H, Stadler M, Thongklang N, Hyde KD 2021 - Cultivation and identification of blazeispirols of Agaricus campestroides and A. flocculosipes. Fungal Biotec 1(2), 101-117, Doi 10.5943/FunBiotec/1/2/7

\begin{abstract}
The genus Agaricus contains many edible and medicinal mushrooms; and some of them are used for commercial purposes. Most Agaricus species have been described from temperate geographic areas, but their occurrence in the tropics is still underexplored. The present study describes the successful cultivation of two wild strains from Thailand, A. flocculopsipes and A. campestroides for the first time. The optimal conditions for mycelial growth have been evaluated for both strains, formation of basidiomata on compost could only be observed for A. campestroides. In the present study, mycelial growth and mushroom production conditions were optimized. The temperature range of $25-30{ }^{\circ} \mathrm{C}$ with $80-90 \%$ humidity was assessed as preferred conditions for primordia and basidiomata formation in a compost rice straw medium with sandy-soil casing layer. Blazeispirols (blazeispirol A and D), a family of triterpenoids that is known to act as selective agonists of Liver $X$ receptor alpha with beneficial effects in vivo in a murine model, were detected in crude extracts from submerged cultures of $A$. campestroides and A.flocculosipes.
\end{abstract}

Keywords - Bioactive compounds - edible mushroom - mushroom farming - Thailand

\section{Introduction}

Agaricus L. (Linnaeus, 1753) is a genus of agaricoid fungi that was erected quite early in mycological history and even today it still forms the core of the Agaricaceae (Basidiomycota). Approximately 500 species have been described in this genus, and they are quite common in various habitats, such as grassland and forests (Callac \& Chen 2018, He et al. 2019). The genus Agaricus is characterized by basidiomata having a fleshy pileus with free lamellae that produce brown spores, and an annulate stipe. Agaricus bisporus (J.E. Lange) Imbach is actually the most extensively cultivated mushroom in the world, accounting for $38 \%$ of world's mushroom production (ISMS Edible mushrooms 2017, http://www.isms.biz/edible-mushrooms/). For Agaricus cultivation, many researchers rely on A. bisporus using the local agro-industrial wastes as substrates. The raw materials that are commonly used to prepare the substrate are sugarcane bagasse, various grasses, cereal straw (Triticum aestivum, Avena sativa, Oryza sativa) and manures supplemented with nitrogen sources (soybean, wheat, corn, cottonseed meal, urea, and ammonium 
sulfate) with sources of phosphorus and calcium (Zied et al. 2011a,b). Experiments performed in China showed the possible use of cottonseed hulls, rice hulls, asparagus straw and soybean cake for compost (Wang et al. 2010, Zhou et al. 2010). Cattle bedding compost/sawdust/cereal bran (Pokhrel \& Ohga 2007) and chicken manure/wheat straw (Gregori et al. 2008) were also used for Agaricus production in temperate countries. Peat, local soils, with or without the addition of vegetal charcoal, have been used in the casing layer for cultivation (Cavalcante et al. 2008, Siqueira et al. 2009, Colauto et al. 2010, Zied et al. 2010)

Another popular edible mushroom, Agaricus subrufescens Peck was cultivated first in the late 1800s in eastern North America (Kerrigan 2005). From a nomenclatural point of view, taxonomists agree that the species has been incorrectly referred as A. blazei Murrill. Therefore, it was proposed by Wasser et al. (2002) as a new species, Agaricus brasiliensis Wasser, Didukh, de Amazonas \& Stamets, and then synonymised by Kerrigan (2005) with A. subrufescens which has priority since it is older. The type consists partly of cultivated material and partly of field-collected specimens and has been produced on a commercial scale in Brazil since the early 1990s (Kerrigan 2005, Braga et al. 2006) and exported to several countries. Nowadays it is also cultivated at industrial level in China, France, Japan, Korea, Taiwan and USA. Agaricus flocculosipes was first described from Thailand, but it is also known from Mayotte Island (Zhao et al. 2012) and China (Gui et al. 2015). The cultivation of A. flocculosipes and A. subrufescens in Thailand were successfully cultivated on standard compost based on wheat straw and horse manure but the yields were low (Thongklang et al. 2014). Based on our current information, 22 mushrooms were successfully cultivated in Thailand for commercial use (Thawthong et al. 2014). Several hybrid strains of Agaricus from Thailand have been developed, focusing on their favourable agronomic behaviour and morphological characteristics (Jatuwong et al. 2014).

Species of Agaricus have high potential for cultivation as many species are edible and possess medicinal properties. A substance class already known from the genus Agaricus are the blazeispirols which were isolated from cultured mycelium of A. blazei ( $=$ A. subrufescens) (Hirotani et al. 1999, 2000, 2001, 2002). Moreover, Stadler et al. (2005) reported a series of triglycerides of chlorinated phenols from mycelial part of liquid cultures of Agaricus macrosporus and several other species in the genus Agaricus. The aromatic metabolites showed potential analgestic effects, owing to their strong inhibitory activity against neurolysin. The blazeispirols from A. subrufescens were discovered as strong and selective agonists of the Liver X receptor (LXR). Significant in vivo effects of blazeispirols in a mouse model were observed which might give rise to the development of a new anti-hypercholesterolemic and antidiabetic agent from cultures of a medicinal mushroom (Grothe et al. 2011).

In this study, Agaricus campestroides and A. flocculosipes were selected for cultivation. Agaricus campestroides belongs to "Tropical clade b" sensu stricto (Zhao et al. 2011) is known as wild edible species from Ethiopia (Dejene et al. 2017). Agaricus flocculosipes is also an edible species belongs to section Arvenses (Zhao et al. 2012). Those mushrooms are potentially cultivable and might be a promising source with potential commercial value for Thailand and other countries. We aim in this study at finding optimal conditions for mycelial growth and the spawn production for mushroom cultivation that can further used for industrial production. The present study also describes the identification of blazeispirols in liquid cultures of Agaricus campestroides and A. flocculosipes which were collected from Thailand.

\section{Materials \& methods}

\section{Sample collection of Agaricus strains}

Two specimens of $A$. campestroides and A. flocculosipes were collected in Mae Fah Luang university campus, Chiang Rai province, Northern Thailand during the rainy season from June to August 2014. The specimens were dried at $45^{\circ} \mathrm{C}$ by hot air dryer and kept in zip-lock plastic bags containing dehydrated silica gel as a desiccant to control humidity. The dried specimens were deposited in the herbarium of Mae Fah Luang University (MFLU herbarium), Chiang Rai, Thailand 
with the accession numbers: MFLU 14-0872 (A. campestroides) and MFLU 14-0874 (A. flocculosipes).

\section{Isolation of mycelial cultures}

Pure cultures were aseptically obtained by transferring sections of internal tissue from wild basidiomata of Agaricus onto potato dextrose agar (PDA) after incubation at $25^{\circ} \mathrm{C}$ in a dark room for 14 days. The isolates were deposited in the culture collections of Mae Fah Luang University (MFLUCC) with the numbers MFLUCC 14-1024 (MFLU 14-0872) and MFLUCC 14-1026 (MFLU 14-0874). The cultures were kept at $4{ }^{\circ} \mathrm{C}, 25^{\circ} \mathrm{C}$, and $-20{ }^{\circ} \mathrm{C}$ for further studies.

\section{DNA extraction, PCR, and sequencing}

Genomic DNA was extracted from dry specimens (ca. $10 \mathrm{mg}$ ) using a CTAB isolation procedure adapted from Doyle \& Doyle (1990). The ITS region was amplified by polymerase chain reaction (PCR). For PCR amplification of the ITS1-5.8S-ITS2 region of rDNA, ITS1-F (Gardes \& Bruns 1993) and ITS4 (White et al. 1990) were used as primers. Raspé et al. (2016) and Chuankid et al. (2019) were followed for the PCR amplification, purification and sequencing of ITS region. The sequences of Thai strains of A. campestroides and A. flocculosipes were deposited in the NCBI database under the accession numbers MZ596239 and MZ596240, respectively.

\section{Optimization of culture conditions for mycelial growth}

Four different media were used for optimizing mycelial growth rates, including malt extract agar (MEA), malt yeast peptone agar (MYPA), potato dextrose agar (PDA), and potato dextrose yeast agar (PDYA), and $\mathrm{pH}$ of the media were adjusted to 6.3. After incubation for 10 days, the growing edge of each colony from pure cultures on PDA was cut out by using a cork-borer $(8 \mathrm{~mm}$ in diameter) and placed on the centre of each optimization medium in $9 \mathrm{~cm}$ petri dishes. Three replicates of each medium were incubated in the dark at $25^{\circ} \mathrm{C}$ for 30 days. Mycelial characteristics, such as colour, margin, and shape on the agar surface were recorded. Biomass of dry mycelium was measured by melting agar medium, drained away the liquid phase of medium, and dried the mycelia at $40{ }^{\circ} \mathrm{C}$ for $24 \mathrm{~h}$. The mycelial dried weight was recorded using an electronic scale (gram). The biomass was measured every three days for 30 days. The day after mycelium fully colonised was selected for statistical analysis.

Mycelial disks $(8 \mathrm{~mm})$ from the colony edge of 10-day-old petri dish cultures of each strain were transferred to optimal medium. The optimal temperature for mycelial growth was determined by using four different temperatures: $20,25,30$ and $35{ }^{\circ} \mathrm{C}$. Three replicates of each strain were incubated in a dark room for 30 days. The biomass was measured as described above.

The medium exhibiting the highest growth rate and optimal temperature was used to evaluate the optimal $\mathrm{pH}$. The $\mathrm{pH}$ was adjusted to $5,6,7$, and 8 with hydrochloric acid $(\mathrm{HCl})$ and sodium hydroxide $(\mathrm{NaOH})$. The $\mathrm{pH}$ range of the media were measured using a digital $\mathrm{pH}$ meter before autoclaving. The biomass of mycelium was measured for each $\mathrm{pH}$ value as described above.

\section{Spawn production}

Spawn is the medium for mushroom mycelium that provides the backbone to any mushroom growing operation (seeds for cultivation). The preparation of spawn was adapted from Royse \& Beelman (2016). Spawn was made by sterilized a mixture of wheat grain mixed with water, $1 \%$ calcium carbonate, and $0.5 \%$ calcium sulfate. The spawn jars containing $100 \mathrm{~g}$ of wheat grain were inoculated with a $1 / 4$ colony from actively growing mycelia of a $9 \mathrm{~mm}$ diameter petri dish and incubated at $25^{\circ} \mathrm{C}$ until mycelium fully colonised.

\section{Cultivation substrate}

The compost was prepared using the outdoor composting method, including 25 days of phase I and 7 days of phase II, totalling 32 days. The formulation used had a dry weight of 1,080 $\mathrm{kg}$ of Oryza sativa, $5.5 \%$ of rice bran, $1.1 \%$ of urea, $2.2 \%$ calcium oxide, and $2.2 \%$ gypsum. The bulk 
materials (O. sativa straw and rice bran) were moistened for 9 days and rotated every 2 days. The concentrated materials (urea, calcium oxide, and gypsum) were added after each turning operation throughout the composting phase I (Table 1).

The casing mixture used contains $15 \%$ peat, $23 \%$ limestone, $37 \%$ fine sand, and $25 \%$ soil, as recommended by Zied et al. (2011a). When the mycelia were fully developed, the compost was pressed and levelled to facilitate the addition of the casing layer to a height of $5 \mathrm{~cm}$. After casing, the trays were watered once a day. The mushroom production was carried out with four replicates trays (Royse 2010, Llarena-Hernández et al. 2011).

\section{Conditions for fructification}

Four trays filled with $5 \mathrm{~kg}$ of compost were inoculated with $5 \%$ spawn and incubated for 30 days in a grow room at $25{ }^{\circ} \mathrm{C}$ with $90 \%$ relative humidity. Then $5 \mathrm{~cm}$ of casing layer was added, and the trays were left under the same environmental conditions for a 7-day post-incubation period. The grow room was then set at $20{ }^{\circ} \mathrm{C}$ with $80 \%$ humidity. Time for mushroom forming was the number of days between casing and the first picking. The numbers and fresh weight of basidiomata were recorded until 65 days after casing. The experiments were performed according to a completely randomized design with four replicates per strain.

\section{Investigation of the secondary metabolite production}

The production of secondary metabolites in submerged cultures was examined in strain $A$. campestroides (MFLUCC 14-1024) and A. flocculosipes (MFLUCC 14-1026) using four different media: yeast malt extract medium (YM), sugar malt extract medium (ZM), cotton seed meal medium (Q6 1/2), and mannitol salt medium (MMK). The mycelium was inoculated in $100 \mathrm{~mL}$ of each medium in 250 -mL Erlenmeyer flasks at $24{ }^{\circ} \mathrm{C}$ and placed on a 140-rpm rotary shaker. After 5 days following the inoculation, the free glucose was measured with glucose test strips daily until the free glucose was consumed and the $\mathrm{pH}$ was checked with a $\mathrm{pH}$ meter (method adapted from Kuhnert et al. 2014). To qualitatively analyse the produced metabolites, an ethyl acetate extraction procedure was used for mycelia and submerged culture supernatant. Liquid media and biomass from liquid cultivation on different media were separated by filtration. Liquid media were discarded due to the lack of compounds. Each mycelium was extracted with acetone $(200 \mathrm{~mL})$ in an ultrasonic bath at room temperature for $30 \mathrm{~min}$. After, the crude extract was filtered and redissolved in deionized water $(100 \mathrm{~mL})$, then partitioned with ethyl acetate $(1 \times 100 \mathrm{~mL})$. The ethyl acetate layers were dried over anhydrous $\mathrm{Na}_{2} \mathrm{SO}_{4}$ and evaporated to dryness (for the yields see Table 2). Due to a lack of standards, no quantification could be performed. All extracts were prepared to 1 $\mathrm{mg} / \mathrm{mL}$ and subjected to analytical HPLC [Agilent 1260 Infinity with diode array detector and C18 Acquity UPLC BEH column $(2.1 \times 50 \mathrm{~mm}, 1.7 \mu \mathrm{m})$ from Waters; solvent A: deionized water (Milli-Q, Millipore, Schwalbach, Germany) $+0.1 \%$ formic acid, solvent B: acetonitrile $+0.1 \%$ formic acid, gradient system: $5 \% \mathrm{~B}$ for $0.5 \mathrm{~min}$ increasing to $100 \% \mathrm{~B}$ in $19.5 \mathrm{~min}$, maintaining $100 \% \mathrm{~B}$ for $5 \mathrm{~min}$, flow rate $=0.6 \mathrm{~mL} \mathrm{~min}^{-1}$, UV detection [190-600 nm], coupled to an ion trap MS (amaZon speed ${ }^{\mathrm{TM}}$, Bruker). Mass spectrometry (MS) and ultraviolet (UV) data of the crude extracts were analysed and compared with the literature data using substance databases (CRC Dictionary of Natural Products, CAS SciFinder, Wiley-VCH Antibase).

Blazeispirols A (1) and D (2) were identified by HPLC-MS comparison (MS, UV/Vis, $t_{\mathrm{R}}$ ) with an authentic sample (for detailed data see in supporting information; SI).

Blazeispirol A (1): UV/Vis: $\lambda_{\text {qual }}=234,269,308 \mathrm{~nm}$; analytical HPLC $\left(t_{\mathrm{R}}\right)=15.6 \mathrm{~min}$; $\mathrm{ESI}(+)-\mathrm{MS}: m / z(\%)=819(5)[2 \mathrm{M}+\mathrm{Na}]^{+}, 381(100)\left[\mathrm{M}+\mathrm{H}-\mathrm{H}_{2} \mathrm{O}\right]^{+}$.

Blazeispirol D (2): UV/Vis: $\lambda_{\text {qual }}=227,272,312 \mathrm{~nm}$; analytical $\operatorname{HPLC}\left(t_{\mathrm{R}}\right)=12.7 \mathrm{~min}$; ESI(+)-MS: $m / z(\%)=367(100)\left[\mathrm{M}+\mathrm{H}-\mathrm{H}_{2} \mathrm{O}\right]^{+}$. 


\section{Statistical analysis}

The optimum growth parameters and mushroom production data were subjected to statistical analysis. The mycelial growth values for growth rate, medium type, biomass, temperature, and $\mathrm{pH}$ optimization were compared to obtain a mean separation using Tukey's test $(p<0.05)$, followed by post hoc tests. The results are expressed in a one-way analysis of variance (ANOVA) analysis using the SPSS program version 19 (IBM Corp.).

\section{Results}

\section{Confirmation of the identity of the cultivated species}

Agaricus campestroides Heinem. \& Gooss.-Font., Bull. Jard. bot. Brux. 26: 20 (1956), new geological record

Index Fungorum number: IF292252

Figs 1, 2

Pileus at first hemispherical, becoming convex, broadly convex to plano-convex; surface white to cream-colour, ochraceous, with greyish to pale ochraceous fibrils darker to margin, dry; margin incurved at first, finally expanding to decurved. Lamellae free, dark brown, crowded, with lamellulae. Stipe central, cylindrical; surface white and silky, white appressed fibrils. Spores print dark brown, anise-like smell.

Basidiospores 6.0-8.0 $\times 4.0-4.5) \mu \mathrm{m}, Q=1.71$, ellipsoid, inamyloid, dark brown, with apical endosporium. Basidia 14-17 × 6-7 $\mu \mathrm{m}$, clavate, 4-spored. Cystidia 9-18 × 7-13 $\mu \mathrm{m}$, subspherical or clavate, hyaline, smooth. Pileipellis a trichoderm; hyphae 9-11 $\mu \mathrm{m}$ in diameter, cylindrical, hyaline. Stipitipellis a cutis of hyphae 6-10 $\mu \mathrm{m}$ in diameter, cylindrical, smooth, hyaline. Clamp connections absent.

Culture characters: After 21 days of incubation in PDYA medium, the agar surface was fully colonized with a white mycelium. The mycelium is linear to thread-like hyphae.

Material examined: Thailand, Chiang Rai, Muang Chiang Rai, Mae Fah University, on grassland, 20 June 2014, B. Chuankid, BC079 (MFLU 14-0872); living culture, MFLUCC 141024.

Hosts: On grassland soil-(Dejene et al. 2017; this study).

Distribution: Ethiopia, Thailand-(Dejene et al. 2017; this study).

GenBank accession numbers: ITS: MZ596239.

Notes: The nrITS nucleotide sequences of MFLU 14-0872 revealed that the most similar sequences were from A. campestroides JF727842 from Togo (Zhao et a. 2011), at 99.03\% similarity with $96 \%$ query cover. From Index Fungorum, this species was listed in Micropsalliota campestroides (Heinem. \& Gooss.-Font.) Heinem. The comparison between the type specimen and our specimen were not similar. The shapes of basidia and cystidia of our specimens were subspherical or clavate, while the type specimen is another shape (claviforms basidia and inconspicuous cystidia). Pileipellis also not incrusted with pigments like other Micropsalliota. From this, our specimen fits to the descriptions of Agaricus.

Agaricus flocculosipes R.L. Zhao, Desjardin, Guinb. \& K.D. Hyde, Mycoscience 53: 302 (2012)

\section{Index Fungorum number: IF561690}

Figs 1, 3

The basidiomata of MFLU 14-0874 that grew in the wild was confirmed as the same species as A. flocculosipes. The floccose stipe, almond odour, well-developed squamules on the pileus, two-layered annulus, and catenulate cheilocystidia were typical of the species (Thongklang et al. 2014).

Basidiospores 5.0-6.5 $\times(3.5-4.0) \mu \mathrm{m}, Q=1.61$, ellipsoid, with apical endosporium, smooth, reddish brown, thick walled. Basidia 10-13 × 4-6 $\mu \mathrm{m}$, clavate, 4-spored. Cystidia 40-46 × 8-12 $\mu \mathrm{m}$, narrowly conical or fusiform to narrowly utriform, hyaline, smooth. Pileipellis a cutis; hyphae 6-8 $\mu \mathrm{m}$ in diameter, cylindrical, straight or curved, with brown pigments. Stipitipellis a cutis of hyphae 5-8 $\mu \mathrm{m}$ in diameter, cylindrical, smooth, hyaline. Clamp connections absent. 
Culture characters: After 21 days of incubation in MYPA medium, the agar surface was colonized with a white mycelium. The mycelium is circular with smooth hyphae.

Material examined: Thailand, Chiang Rai, Muang Chiang Rai, Mae Fah University, on grassland, (date) 9 Jul 2014, B. Chuankid, MFLU 14-0874.

Hosts: on rich soil or over heavily rotted wood in forests or grassland soil-(Zhao et al. 2012; Gui et al. 2015; this study).

Distribution: Thailand and China-(Zhao et al. 2012; Gui et al. 2015; this study).

GenBank accession numbers: ITS: MZ596240.

Notes: The collection has identical morphology with A. flocculosipes, nrITS nucleotide sequence was subjected to a BLAST search against the NCBI database. The nrITS nucleotide sequences in the NCBI database revealed that the most similar sequences were from $A$. flocculosipes KP705076 from Thailand (Thongklang et al. 2016), at 100\% similarity with 96\% query cover.
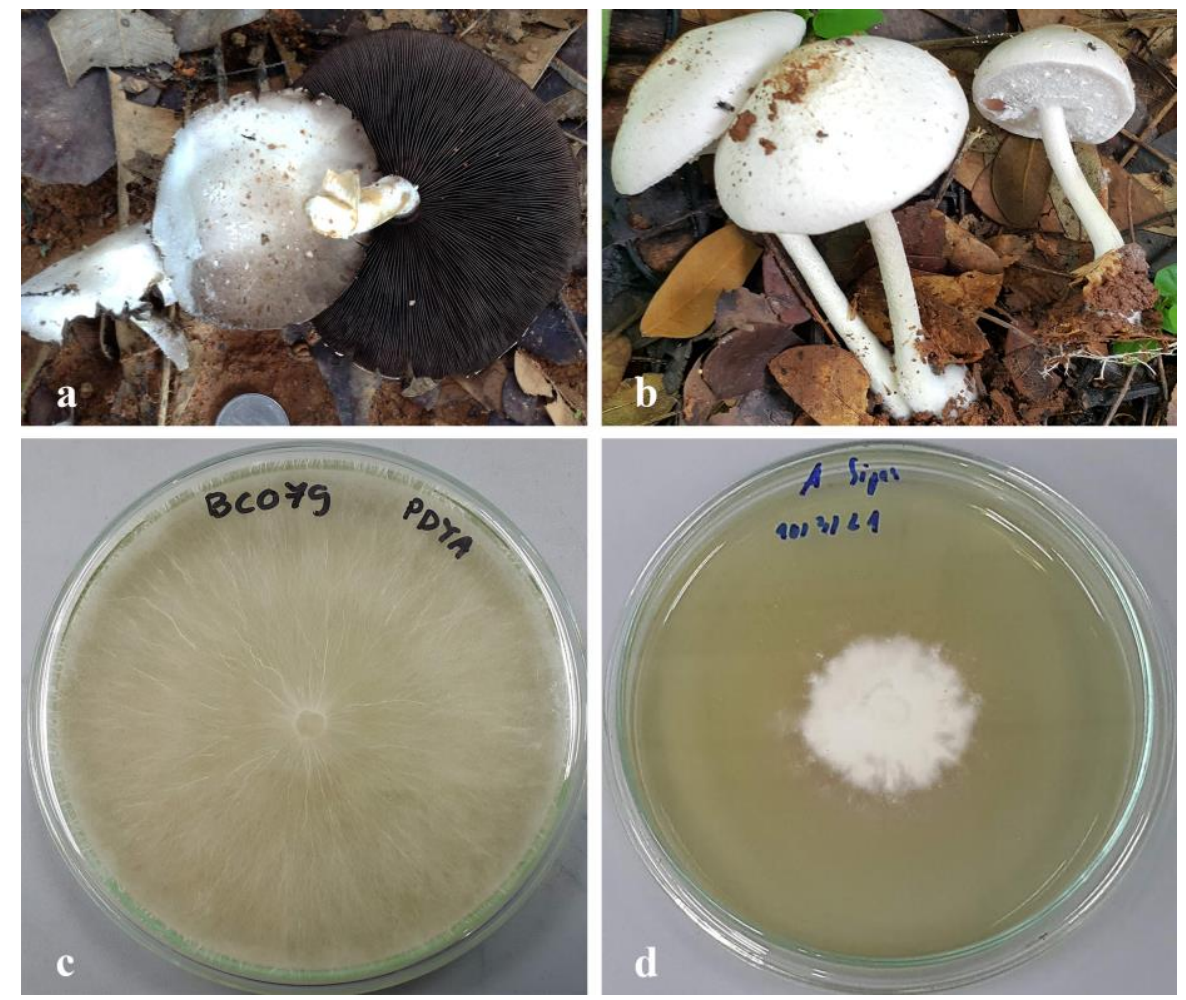

Fig. 1 - a Agaricus campestroides (MFLU 14-0872). b Agaricus flocculosipes (MFLU 14-0874) in the wild. c The mycelial growth of A. campestroides on PDYA medium, d Agaricus flocculosipes on MYPA medium after 30 days.

\section{Effect of media on mycelial growth}

In A. campestroides, the largest radial mycelial growth was observed on PDYA, MEA, PDA, and MYPA, respectively. The colour characteristics of the surface mycelium were not different for the four media types. The morphology of the colony was filamentous on all media. The maximum yield by dry weight mycelium occurred on PDYA, followed by MEA, PDA, and MYPA. The same mycelial character was found on A. flocculosipes (MFLU 14-0874). The maximum yield by dry weight mycelium occurred on MYPA, followed by PDYA, PDA, and MEA but the data were not significantly different among four media. The effect of four agar media on mycelial growth (biomass, mg) are given in Table 1.

\section{Effect of temperature on mycelial growth}

The optimal temperature for mycelial growth of $A$. campestroides is between 20 to $30{ }^{\circ} \mathrm{C}$ and A. flocculosipes was growing well at $25^{\circ} \mathrm{C}$. (Table 1). 


\section{Effect of pH on mycelial growth}

The optimal $\mathrm{pH}$ of $A$. campestroides was $\mathrm{pH} 5$ with the optimal medium and temperature. The result form this study showed that optimal $\mathrm{pH}$ range for mycelial growth of $A$. flocculosipes (MFLU 14-0874) was between 5 to 8. The effects of $\mathrm{pH}$ on mycelial growth (biomass, mg) are given in Table 1.

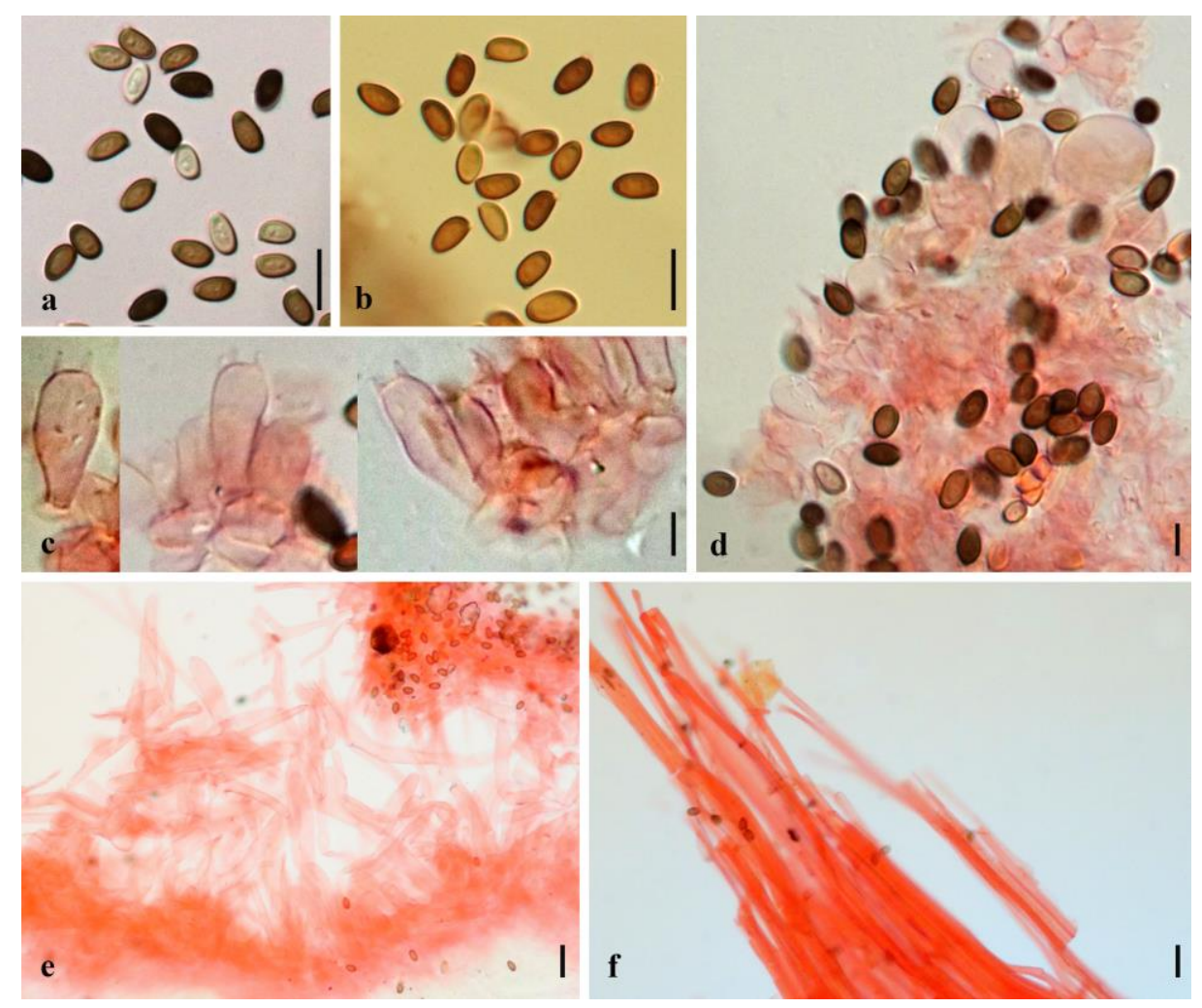

Fig. 2 - Microscopic characteristics of Agaricus campestroides (MFLU 14-0872). a Basidiospores in KOH. b Basidiospores in Melzer's reagent. c Basidia. d Cystidia. e Pileipellis. f Stipitipellis. Bars: $\mathrm{a}, \mathrm{b}=10 \mu \mathrm{m} ; \mathrm{c}, \mathrm{d}, \mathrm{f}=5 \mu \mathrm{m} ; \mathrm{e}=20 \mu \mathrm{m}$.

Table 1 Effect of different agar media, temperature, and $\mathrm{pH}$ on mycelial growth (biomass, $\mathrm{mg}$ ) of A. campestroides and A. flocculosipes. Biomass data $=$ mean weight of dried mycelium \pm standard deviation. Values with the same letter are not significantly different $(p<0.05)$ by Tukey's test.

\begin{tabular}{llc}
\hline Medium name & \multicolumn{2}{c}{ Biomass $(\mathrm{mg})$} \\
\cline { 2 - 3 } & A. campestroides & A. flocculosipes \\
\hline MEA & $109.99 \pm 0.07898^{\mathrm{a}}$ & $11.23 \pm 0.00250^{\mathrm{a}}$ \\
PDA & $23.58 \pm 0.01838^{\mathrm{c}}$ & $13.47 \pm 0.00347^{\mathrm{a}}$ \\
MYPA & $96.12 \pm 0.06923^{\mathrm{b}}$ & $21.07 \pm 0.00196^{\mathrm{a}}$ \\
PDYA & $115.51 \pm 0.08054^{\mathrm{a}}$ & $19.17 \pm 0.00151^{\mathrm{a}}$ \\
Temperature $\left({ }^{\circ} \mathrm{C}\right)$ & & \\
20 & $50.30 \pm 0.05030^{\mathrm{b}}$ & $4.90 \pm 0.00490^{\mathrm{b}}$ \\
25 & $73.53 \pm 0.07353^{\mathrm{a}}$ & $10.83 \pm 0.01083^{\mathrm{a}}$ \\
30 & $80.67 \pm 0.08067^{\mathrm{a}}$ & $3.20 \pm 0.00320^{\mathrm{b}}$ \\
35 & $6.63 \pm 0.00663^{\mathrm{c}}$ & $3.10 \pm 0.00310^{\mathrm{b}}$ \\
pH & & \\
5 & $37.33 \pm 0.03733^{\mathrm{a}}$ & $18.17 \pm 0.002^{\mathrm{a}}$ \\
6 & $1.77 \pm 0.00177^{\mathrm{b}}$ & $15.67 \pm 0.009^{\mathrm{a}}$ \\
7 & $2.47 \pm 0.00247^{\mathrm{b}}$ & $15.36 \pm 0.002^{\mathrm{a}}$ \\
8 & $0.63 \pm 0.00063^{\mathrm{b}}$ & $17.87 \pm 0.001^{\mathrm{a}}$ \\
\hline
\end{tabular}




\section{Spawn production}

Mycelium started to colonize the substrates after five days of incubation, and fully grown within two weeks (Fig. 4). Interestingly, the primordia started to form in three or four weeks of incubation. After one week, the pinning and mushrooms formed in wheat grain spawn.
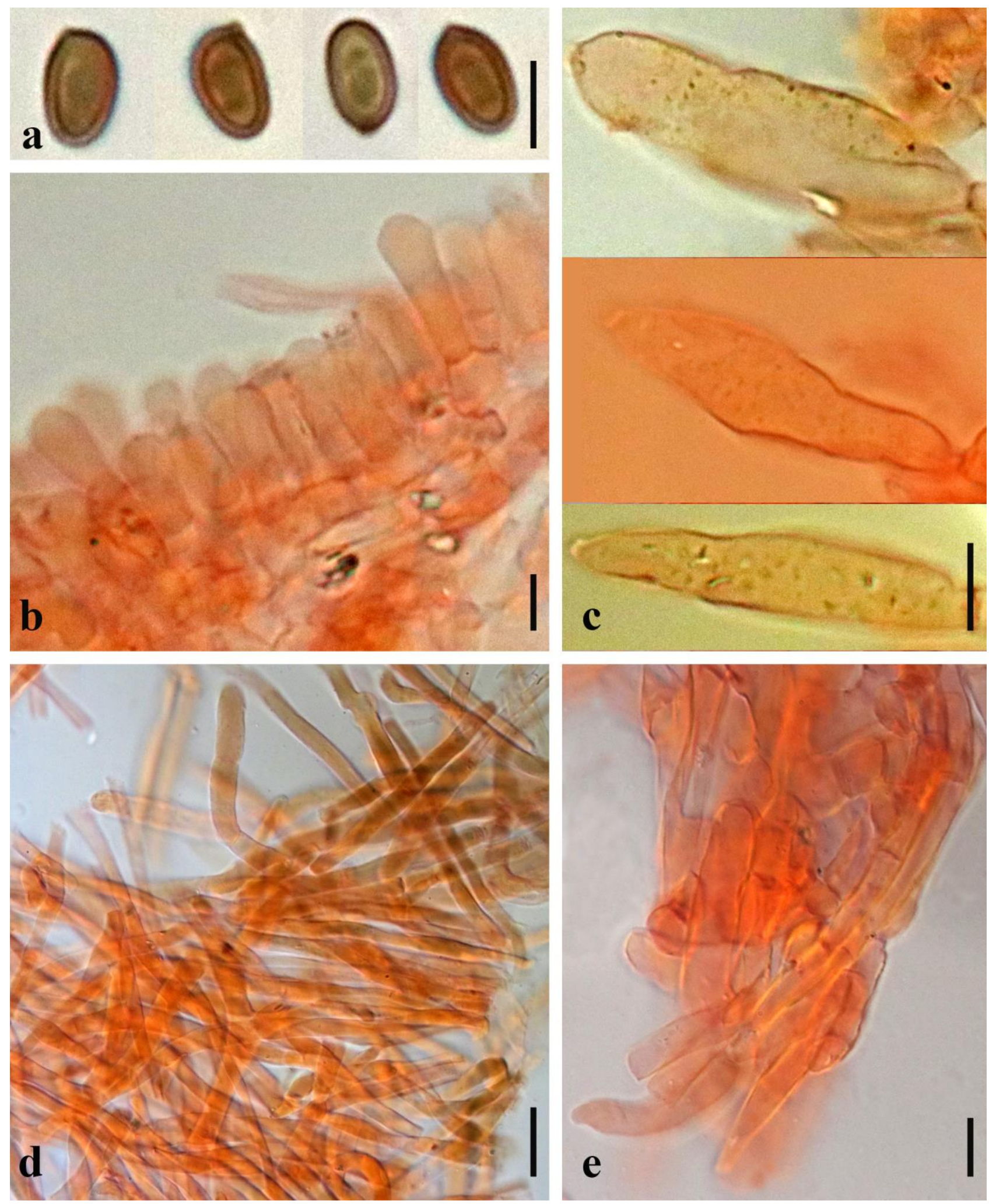

Fig. 3 - Microscopic characteristics of Agaricus flocculosipes (MFLU 14-0874). a Basidiospores in $\mathrm{KOH}$. b Basidia. c Cystidia. d Pileipellis. e Stipitipellis. Bars: $\mathrm{a}, \mathrm{b}=5 \mu \mathrm{m}$; $\mathrm{c}, \mathrm{e}=10 \mu \mathrm{m} ; \mathrm{d}=20$ $\mu \mathrm{m}$. 


\section{Harvesting/production}

Approximately 30 days after, mycelium colonized the entire compost. Pre-primordia and mature basidiomata formed on the surface of the casing layer after 20 days at $25{ }^{\circ} \mathrm{C}$. Dense hyphal growth always formed on the edge of casing where basidiomata produced. Successfully cultivated Thai strain of A. campestroides is shown in Fig. 5, but the yields were still very low. Unfortunately, the Thai strain of A. flocculosipes could not be cultivated.
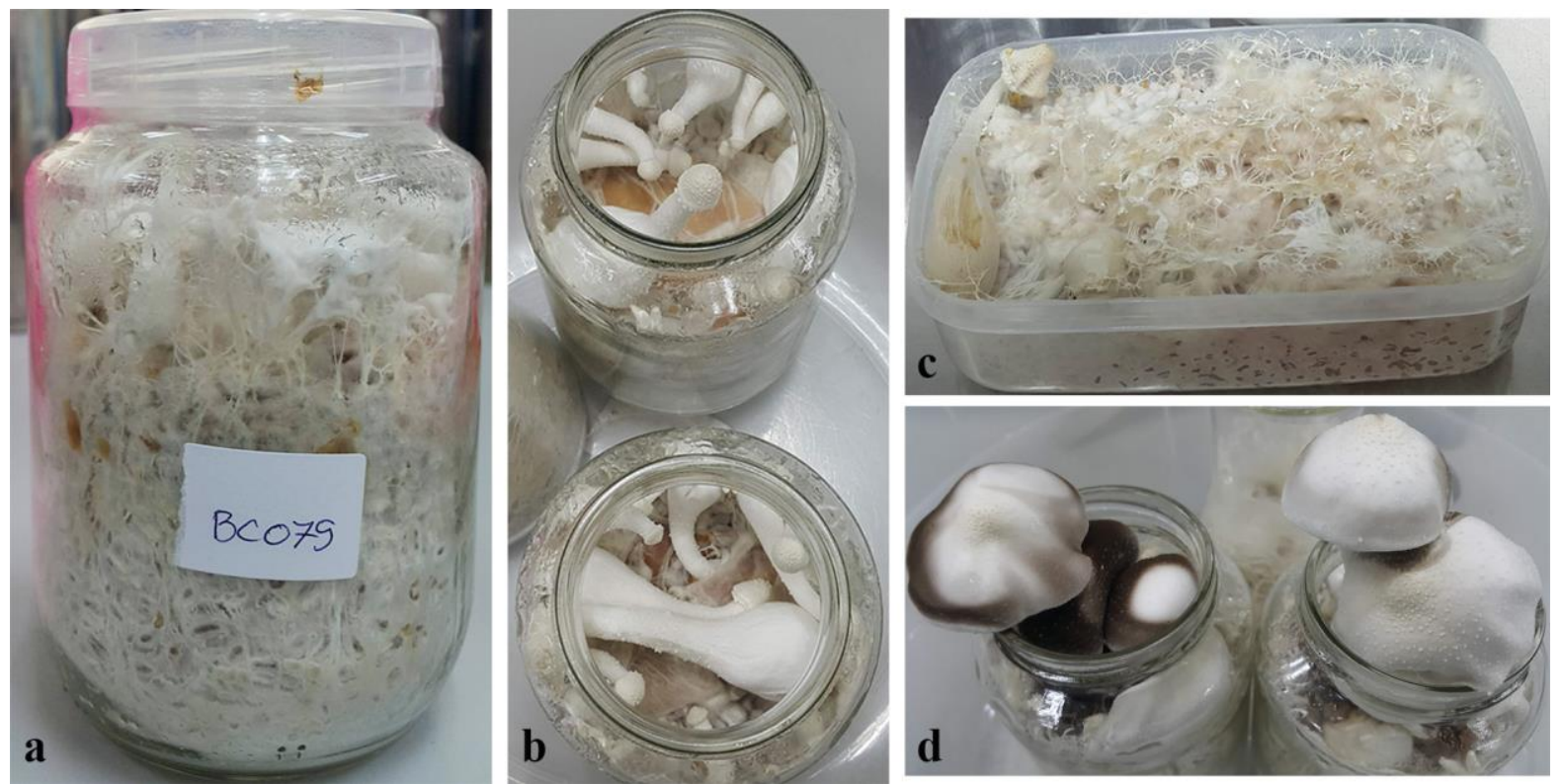

Fig. 4 - Mycelial growth of Agaricus campestroides on wheat grain spawn after 14 days. a, c Mycelium fully colonised on substrate in different container. b, d A week after mycelium fully colonised, the primordia and mushrooms formed in spawn.
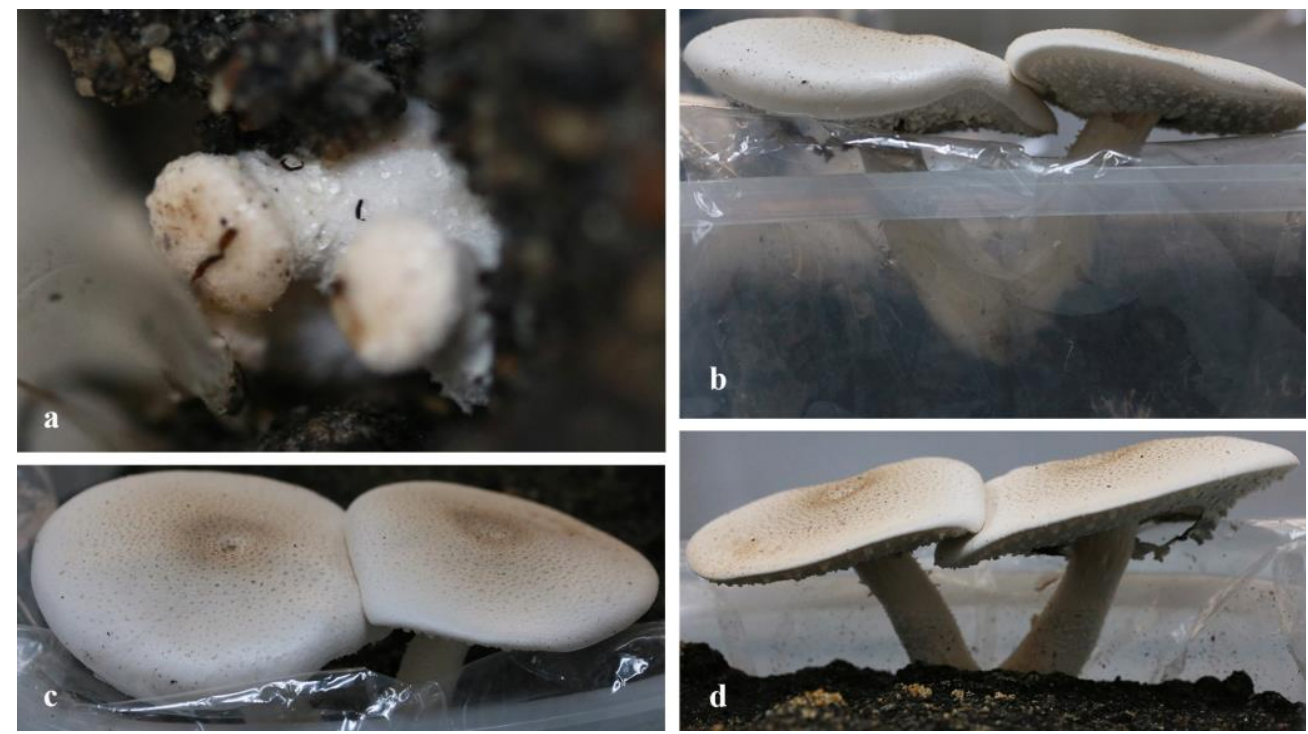

Fig. 5 - The basidiomata of A. campestroides (MFLU 14-0872) on compost medium after 20 days of casing at $20^{\circ} \mathrm{C}$ with $80 \%$ humidity.

\section{HPLC profiling and detection of blazeispirol}

The crude extracts of A. campestroides and A. flocculosipes were screened for their secondary metabolites in four different liquid media by HPLC-UV/Vis and HPLC-MS. Investigation on the crude extracts indicated the presence of the triterpenoids blazeispirol A (1) and D (2) (Fig. 6), which could be detected from the mycelia of both strains. The compounds were identified based on 
their spectral data [UV/Vis, ESI(+)-MS] and HPLC comparison with an authentic sample. Herein, blazeispirol A (1) was observed as the main component of the crude extracts, while blazeispirol D (2) could only detected in small amounts (Fig. 7). Although blazeispirol A (1) could be identified in both mycelium and supernatant of the crude extracts, but the larger amounts was significantly present in mycelium. Comparison of the metabolic profiles of different liquid media demonstrated that the highest production of the compounds (1 and 2) was found in mannitol salts medium (MMK) for both strains and YM in case of A. flocculosipes (Table 3).

Whereas blazeispirol 1 has not yet been detected in the basidiomata, it is produced in large quantities by liquid mycelium fermentation of A. blazei (Grothe et al. 2016). Further investigations hypothesized that blazeispirol D (2) and Z seemed to be the actual intermediates of the blazeispirol A biosynthesis, which might be derived from ergosterol (Hirotani et al. 2001).

According to the MS spectra of the observed compounds, the chlorinated triglycerides could not be detected in any extract.

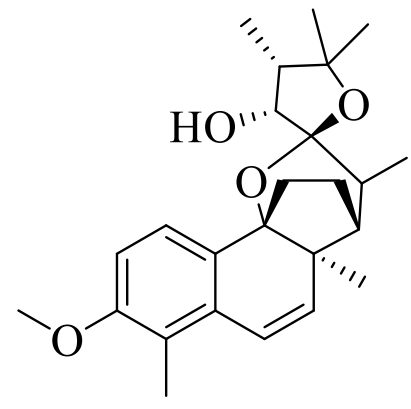

blazeispirol A (1)

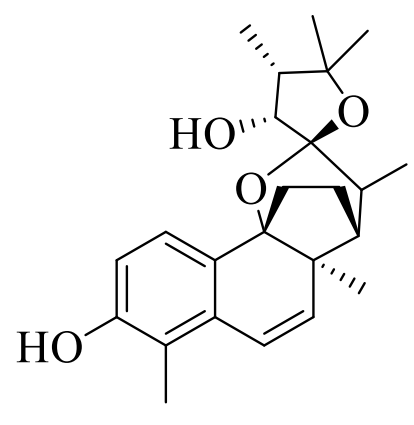

blazeispirol D (2)

Fig. 6 - Chemical structures of blazeispirol A (1) and D (2).

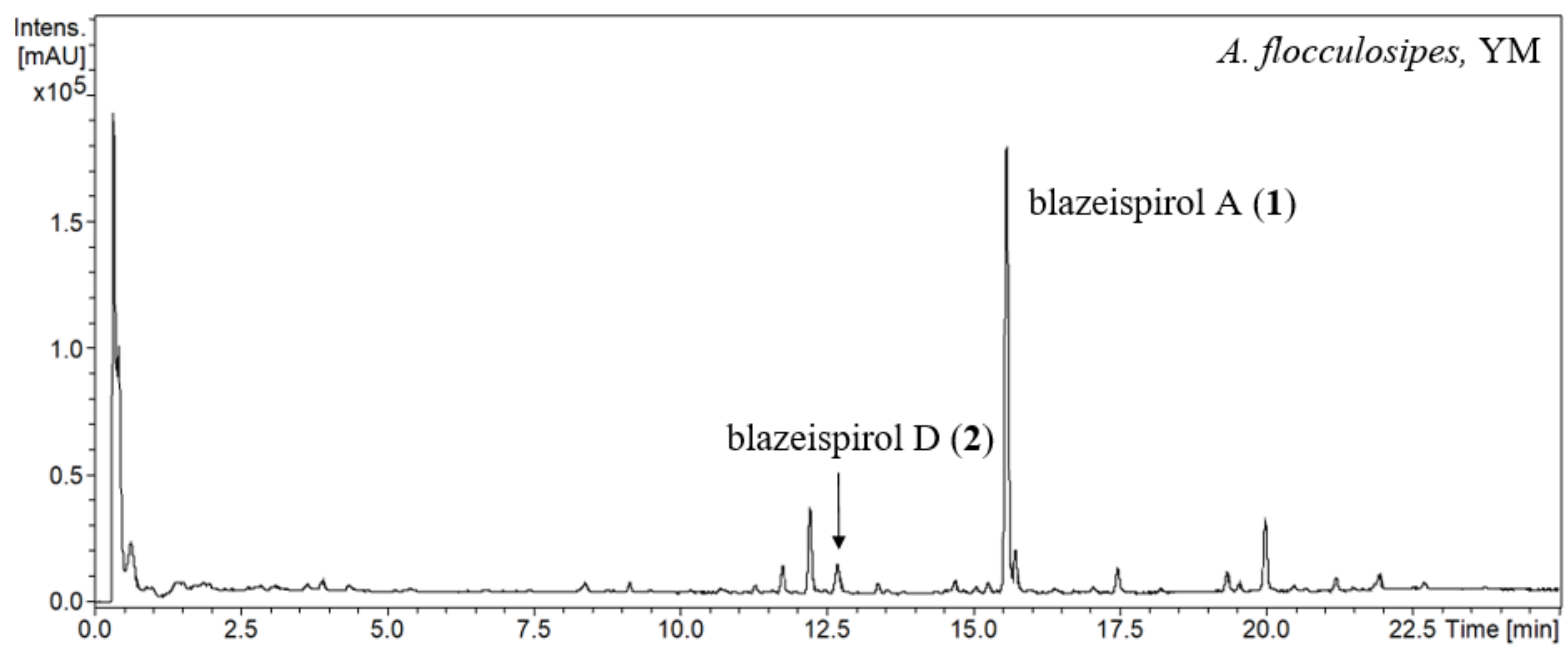

Fig. 7 - HPLC-UV/Vis chromatogram of the crude extract of A. flocculosipes cultivated in YMmedium (190-600 nm).

\section{Discussion}

This present study demonstrates the successful cultivation and domestication of $A$. campestroides, collected in northern Thailand. For this purpose, the optimal culture medium, $\mathrm{pH}$, temperature, and yield were investigated for the best mycelial growth. For the two strains, used in this study, the best growth rates were obtained using PDYA for A. campestroides and all media were suitable for A. flocculosipes. The two strains of Agaricus showed optimal temperature between $25-30{ }^{\circ} \mathrm{C}$ for mycelial growth which is consistent with the previous study by Zied et al. 
(2011b). Agaricus campestroides was growing well at pH 5 while A.flocculosipes was able to grow at $\mathrm{pH}$ 5-8. Park (2001) reported the optimal $\mathrm{pH}$ for the substrate reaction range between 6-7, high acid or basic condition inhibited mycelial growth. Kopytowski et al. (2008) reported that the optimal $\mathrm{pH}$ range for compost substrate and casing layer is $\mathrm{pH}$ 7.0-7.5. It is suggested that neutral $\mathrm{pH}$ was the suitable $\mathrm{pH}$ for these mushroom strains.

The two strains of Agaricus were cultivated by using rice straw as the main substrate mixed with the ingredients. Only A. campestroides were produced at the temperature of $20{ }^{\circ} \mathrm{C}$ with $80 \%$ relative humidity 14 days after the casing layer was applied. The mushroom requires high temperature and high humidity to produce mushrooms like A. subrufescens (Dias et al. 2004, Mantovani et al. 2007, Dias 2010). The humidity during the formation of primordia was at 80 $90 \%$, while $75-80 \%$ relative humidity was maintained during the development of mushrooms (Iwade \& Mizuno 1997, Stamets 2000). According to Chang (2008), humidity of 70-85\% was the optimum for mushroom formation. The wild strains of $A$. campestroides showed a potential to grow in northern Thailand since the optimal conditions for growing these stains were temperature range from $25-30{ }^{\circ} \mathrm{C}$ with $80-90 \%$ relative humidity that is related with the weather in northern Thailand (Thai Meteorological Department, 2015).

Moreover, the study of secondary metabolites of A. campestroides and A. flocculosipes has led to the identification of blazeispirols A (1) and D (2) in cultured mycelia of both species.

So far, blazeispirols (A, B, C, D, E, F, G, X, Y, Z) are a class of unique spiro-triterpenoids, isolated from cultured mycelia of Agaricus blazei (=A. subrufescens) (Hirotani et al. 1999, 2000, 2001, 2002) Therefore, the detection of blazeispirols in other species of Agaricus extends the natural occurrence of these type of compounds. Since it was assumed that their occurrence is restricted to A. subrufescens, blazeispirol A (1) was constituted as a phylogenetic and chemotaxonomical marker for this taxon (Thongklang et al. 2017).

Table 2 Yields of crude extracts from the mycelia of A. campestroides and A.flocculosipes cultivated in different media.

\begin{tabular}{lcccc}
\hline \multirow{2}{*}{ Strains } & \multicolumn{4}{c}{ Yields (mg) } \\
\cline { 2 - 5 } & MMK & Q6 $1 / 2$ & YM & ZM \\
\hline A. campestroides & 3.2 & 10.6 & 1.9 & 1.8 \\
A. flocculosipes & 3.3 & NG & 4.5 & 4.5 \\
\hline
\end{tabular}

(NG): not growth.

Table 3 Occurrence of compounds $\mathbf{1}$ and $\mathbf{2}$ in the mycelia of A. campestroides and A. flocculosipes cultivated in different media.

\begin{tabular}{lcccccccc}
\hline & \multicolumn{4}{c}{ A. campestroides } & \multicolumn{3}{c}{ A.flocculosipes } \\
\cline { 2 - 9 } & MMK & Q6 $1 / 2$ & YM & ZM & MMK & Q6 1/2 & YM & ZM \\
\hline Blazeispirol A (1) & +++ & ++ & ++ & - & +++ & NG & +++ & ++ \\
Blazeispirol D (2) & + & - & - & - & ++ & NG & ++ & - \\
\hline
\end{tabular}

$(-)$ : not observed, $(+)$ : observed in traces, $(++)$ : observed in small amounts, $(+++)$; observed in high amounts, (NG): not growth.

\section{Conclusion}

The two strains of Agaricus from northern Thailand were cultivated by using rice straw as the main substrate mixed with the ingredients. The basidiomata were only produced from A. campestroides at the temperature of $20{ }^{\circ} \mathrm{C}$ with $80 \%$ relative humidity 14 days after the casing layer was applied. The best rates of mycelial growth were obtained using PDYA medium adjusted to $\mathrm{pH} 5$ for $A$. campestroides and incubated between 20 to $30{ }^{\circ} \mathrm{C}$. All media were suitable for mycelial growth of $A$. flocculosipes. The mycelial of $A$. flocculosipes was growing well at $25{ }^{\circ} \mathrm{C}$ and at $\mathrm{pH} 5-8$. The study of secondary metabolites of $A$. campestroides and A. flocculosipes has led 
to the identification of blazeispirols A (1) and D (2) in cultured mycelia of both species. Agaricus cultivation conditions will benefit Thai farmers. Compost production from rice straw would help to reduce the burning of rice straw in Thai rice fields. Futhermore, A. campestroides and A. flocculosipes could be served as additional sources for blazeispirols and their potential medicinal properties.

\section{Acknowledgements}

Financial support by the Research and Researchers for Industries grant (PHD57I0015) and Thailand Science Research and Innovation (TSRI) grant, Macrofungi diversity research from the Lancang-Mekong watershed and surrounding areas (Grant No. DBG6280009). Many thanks to Olivier Raspé and Luis A. Parra for their suggestions on species identification. The help of Anan Thawthong and Kritsana Jatuwong at Mae Fah Luang University in mushrooms collecting and cultivation is acknowledged. Thanks to Sebastian Pfütze who gave us the analytical data of the compounds. Finally, B.C. would like to thank Benjarong Thongbai for her support during the stay in Germany.

\section{References}

Braga GC, Montini RMC, Salibe AB. 2006 - Parâmetros da produção de Agaricus blazei sob diferentes condições ambientais de cultivo. Scientia Agraria Paranaensis 5, 47-56.

Callac P, Chen J. 2018 - Tropical species of Agaricus. In: Sánchez JE, Mata G, Royse DJ (Eds.) Updates on tropical mushrooms. Basic and applied research. San Cristobal de Las Casas, Chiapas 25-38.

Cavalcante JLR, Gomes VFF, Kopytowski Filho J, Minhoni MTDA et al. 2008 - Cultivation of Agaricus blazei in the environmental protection area of the Baturité region under three types of casing soils. Acta Scientiarum. Agronomy 30, 513-517. Doi 10.4025/actasciagron.v30i4.5309.

Chang ST. 2008 - Overview of mushroom cultivation and utilization as functional foods. W, Mushrooms as functional foods. Cheung PCK (ed.). J Wiley \& Sons Inc, 1-33.

Chuankid B, Vadthanarat S, Hyde KD, Thongklang N et al. 2019 - Three new Phylloporus species from tropical China and Thailand. Mycological Progress 18, 603-614. Doi 10.1007/s11557019-01474-6.

Colauto NB, da Silveira AR, da Eira AF, Linde GA. 2010 - Alternative to peat for Agaricus $\begin{array}{lllll}\text { brasiliensis yield. } & \text { Bioresource } & \text { Technology }\end{array}$ Doi 10.1016/j.biortech.2009.08.052.

Dejene T, Oria-de-Rueda JA, Martín-Pinto P. 2017 - EDIBLE WILD MUSHROOMS OF ETHIOPIA: NEGLECTED NON-TIMBER FOREST PRODUCTS. Revista Fitotecnia Mexicana 40, 391-397.

Dias ES, Abe C, Schwan RF. 2004 - Truths and myths about the mushroom Agaricus blazei. Scientia agricola 61, 545-549.

Dias ES. 2010 - Mushroom cultivation in Brazil, challenges and potential for growth. Science and Agrotechnology Lavras 34, 795-803.

Doyle JJ, Doyle JL. 1990 - Isolation of plant DNA from fresh tissue. Focus 12, 13-15.

Gregori A, Pahor B, Glaser R, Pohleven F. 2008 - Influence of carbon dioxide, inoculum rate, amount and mixing of casing soil on Agaricus blazei fruiting bodies yield. Acta Agriculturae Slovenica 91, 371-378.

Gardes M, Bruns TD. 1993 - ITS primers with enhanced specificity for basidiomycetes application to the identification of mycorrhizae and rusts. Molecular Ecology 2, 113-118.

Grothe T, Stadler M, Köpcke B, Roemer E, Bitzer J, Wabnitz P. 2016 - Terpenoid Spiro Ketal Compounds with LXR Agonists Activity, Their Use and Formulations with Them. US $9.453,016$ B2. 
Gui Y, Zhu GS, Callac P, Hyde KD et al. 2015 - Agaricus section Arvenses: three new species in highland subtropical Southwest China. Fungal Biology 119, 79-94. Doi 10.1016/j.funbio.2014.10.005.

He MQ, Zhao RL, Hyde KD, Dominik B et al. 2019 - Notes, outline and divergence times of Basidiomycota. Fungal Diversity 99, 105-367. Doi 10.1007/s13225-019-00435-4.

Hirotani M, Hirotani S, Takayanagi H, Yoshikawa T. 1999 - Blazeispirol A, an unprecedented skeleton from the cultured mycelia of the fungus Agaricus blazei. Tetrahedron letters 40, 329-332.

Hirotani M, Hirotani S, Yoshikawa T. 2000 - Blazeispirol X and Y, two novel carbon skeletal sterols from the cultured mycelia of the fungus Agaricus blazei. Tetrahedron Letters 41, 5107-5110.

Hirotani M, Hirotani S, Yoshikawa T. 2001 - Blazeispirol D and Z, as the actual intermediates of blazeispirol A biosynthesis from the cultured mycelia of the fungus Agaricus blazei. Tetrahedron Letters 42, 5261-5264.

Hirotani M, Sai K, Hirotani S, Yoshikawa T. 2002 - Blazeispirols B, C, E and F, des- $A$-ergostanetype compounds, from the cultured mycelia of the fungus Agaricus blazei. Phytocheistry 5, 571-577.

Iwade I, Mizuno T. 1997 - Cultivation of Kawariharatake (Agaricus blazei Murill). Food reviews international 13, 338-390.

Jatuwong K, Kakumyan P, Chamyuang S, Chukeatirote E et al. 2014 - Optimization condition for cultivation of Agaricus subrufescens hybrid strains; The 26th Annual meeting of the Thai Society for Biotechnology and International Conference. Mae Fah Luang University, Chiang Rai, Thailand.

Kerrigan RW. 2005 - Agaricus subrufescens, a cultivated edible and medicinal mushroom, and its synonyms. Mycologia 97, 12-24.

Kopytowski Filho J, Minhoni MTA, Andrade MCN, Zied D. 2008 - Effect of compost supplementation (soybean meal and Champfood) at different phases (spawning and before casing) on productivity of Agaricus blazei ss. Heinemann (A. brasiliensis). International Society for Mushroom Science 17, 260-270.

Kuhnert E, Fournier J, Peršoh D, Luangsa-ard JJ et al. 2014 - New Hypoxylon species from Martinique and new evidence on the molecular phylogeny of Hypoxylon based on ITS rDNA and $\beta$-tubulin data. Fungal Diversity. 64, 181-203.

Llarena-Hernández CR, Largeteau ML, Ferrer N, Regnault-Roger C et al. 2014 - Optimization of the cultivation conditions for mushroom production with European wild strains of Agaricus subrufescens and Brazilian cultivars. Journal of the Science of Food and Agriculture 94, 7784. Doi 10.1002/jsfa.6200.

Linnaeus C. 1753 - Species plantarum, exhibentes plantas rite cognitas ad genera relatas cum differentiis specificis, nominibus trivialibus, synonymis selectis, locis natalibus, secundum systema sexuale digestas. Stockholm.

Mantovani TRD, Linde GA, Colauto NB. 2007 - Effect of addition of nitrogen sources to cassava fiber and carbon-to-nitrogen ratios on Agaricus brasiliensis growth. Canadian Journal of Microbiology 53, 139-143.

Park JS. 2001 - Characteristics and Cultivation Technology of Agaricus blazei. MushWorld website, http//www.mushworld.com (Accessed on June 20, 2021).

Pokhrel CP, Ohga S. 2007 - Cattle bedding waste used as a substrate in the cultivation of Agaricus blazei Murill. Journal of the Faculty of Agriculture, Kyushu University 52, 295-298.

Raspé O, Vadthanarat S, De Kesel A, Degreef J et al. 2016 - Pulveroboletus fragrans, a new Boletaceae species from Northern Thailand, with a remarkable aromatic odor. Mycological Progress 15, 38. Doi 10.1007/s11557-016-1179-7.

Royse DJ. 2010 - Effects of fragmentation, supplementation and the addition of phase II compost to 2nd break compost on mushroom (Agaricus bisporus) yield. Bioresource technology 101, 188-92. 
Royse DJ, Beelman RB. 2016 - Six steps to mushroom farming. Received from https://extension.psu.edu/six-steps-to-mushroom-farming (Accessed on June 20, 2021).

Stadler M, Hellwig V, Mayer-Bartschmid A, Denzer D et al. 2005 - Novel analgesic triglycerides from cultures of Agaricus macrosporus and other basidiomycetes as selective inhibitors of neurolysin. The Journal of antibiotics. 58, 775-86.

Stamets P. 2000 - Growing Gourmet and Medicinal Mushrooms. Ten Speed Press, Berkeley, CA, 574

Siqueira FG, Dias ES, Silva RD, Martos ET et al. 2009 - Cultivation of Agaricus blazei ss. Heinemann using different soils as source of casing materials. Scientia Agricola 66, 827-830. Doi 10.1590/S0103-90162009000600016.

Sarakham M, Et R, Chaiyaphum Y, Charoen A et al. 2015 - The Climate of Thailand. Thai Meteorological Department. https://www.tmd.go.th (Accessed on June 20, 2021).

Thawthong A, Karunarathna SC, Thongklang N, Chukeatirote E et al. 2014 - Discovering and domesticating wild tropical cultivatable mushrooms. Chiang Mai Journal of Science 41, 731764.

Thongklang N, Sysouphanthong P, Callac P, Hyde KD. 2014 - First cultivation of Agaricus flocculosipes and a novel Thai strain of A. subrufescens. Mycosphere 5, 814-820.

Thongklang N, Chen J, Bandara AR, Hyde KD et al. 2016 - Studies on Agaricus subtilipes, a new cultivatable species from Thailand, incidentally reveal the presence of Agaricus subrufescens in Africa. Mycoscience 57, 239-250.

Thongklang N, Thongbai B, Chamyuang S, Callac P et al. 2017 - Blazeispirol A, a chemotaxonomic marker from mycelia of the medicinal mushroom Agaricus subrufescens. Chiang Mai Journal of Science 44, 298-308.

Wang Q, Li BB, Li H, Han JR. 2010 - Yield, dry matter and polysaccharides content of the mushroom Agaricus blazei produced on asparagus straw substrate. Scientia horticulturae 125, 16-18. Doi 10.1016/j.scienta.2010.02.022.

Wasser SP, Didukh MY, de Amazonas MAL, Nevo E et al. 2002 - Is a widely cultivated culinarymedicinal royal sun Agaricus (the Himematsutake Mushroom) indeed Agaricus blaze Murrill? International Journal of Medicinal Mushrooms 4, 267-290.

White TJ, Bruns T, Lee S, Taylor J. 1990 - Amplification and direct sequencing of fungal ribosomal RNA genes for phylogenetics. PCR protocols: a guide to methods and applications $18,315-322$.

Zhao R, Karunarathna S, Raspé O, Parra LA et al. 2011 - Major clades in tropical Agaricus. Fungal Diversity 51, 279-296. Doi 10.1007/s13225-011-0136-7.

Zhao RL, Hyde KD, Desjardin DE, Raspé O et al. 2012 - Agaricus flocculosipes sp. nov., a new potentially cultivatable species from the palaeotropics. Mycoscience 53, 300-311.

Zhou Q, Tang X, Huang Z, Song P et al. 2010 - Novel method for cultivating Agaricus blazei. Acta Edulis Fungi 17, 39-42. http://www.syjxb.com/EN/Y2010/V17/I02/43 (Accessed on June 20, 2021).

Zied DC, Minhoni MTA, Kopytowski-Filho J, Andrade MC et al. 2010 - Production of Agaricus blazei ss. Heinemann (A. brasiliensis) on different casing layers and environments. World Journal of Microbiology and Biotechnology 26, 1857-1863. Doi 10.1007/s11274-010-0367-X.

Zied DC, Minhoni MTA, Kopytowski-Filho J, Barbosa L et al. 2011a - Medicinal mushroom growth as affected by non-axenic casing soil. Pedosphere 21, 146-153. Doi 10.1016/S1002-0160(11)60112-4.

Zied DC, Pardo-Gime'nez A, Savoie JM, Pardo-Gonzalez JE et al. 2011b - indoor method of composting and genetic breeding of the strains to improve yield and quality of the almond mushroom Agaricus subrufescens; Proceedings of the seventh International Conference on Mushroom Biology and Mushroom Products (ICMBMP7), 419-427. 


\section{Supplementary data}

\section{Supporting information:}

Blazeispirol $A$ (1) [authentic sample]: UV/Vis: $\lambda_{\text {qual }}=236,268,308 \mathrm{~nm}$; analytical HPLC $\left(t_{\mathrm{R}}\right)=$ $15.20 \mathrm{~min} ; \mathrm{ESI}(+)-\mathrm{MS}: \mathrm{m} / z(\%)=819(5)[2 \mathrm{M}+\mathrm{Na}]^{+}, 381(100)\left[\mathrm{M}+\mathrm{H}-\mathrm{H}_{2} \mathrm{O}\right]^{+}$.

Blazeispirol D (2) [authentic sample]: UV/Vis: $\lambda_{\text {qual }}=229,270,310 \mathrm{~nm}$; analytical HPLC $\left(t_{\mathrm{R}}\right)=$ $12.40 \mathrm{~min} ; \mathrm{ESI}(+)-\mathrm{MS}: m / z(\%)=791(6)[2 \mathrm{M}+\mathrm{Na}]^{+}, 367(100)\left[\mathrm{M}+\mathrm{H}-\mathrm{H}_{2} \mathrm{O}\right]^{+}$.

Identification of blazeispirol A (1) and D (2) in Agaricus flocculosipes (MFLU 14-0874):

Blazeispirol A (1): UV/Vis: $\lambda_{\text {qual }}=234,269,308 \mathrm{~nm}$; analytical HPLC $\left(t_{\mathrm{R}}\right)=15.6 \mathrm{~min}$; ESI(+)-MS: $m / z(\%)=819(5)[2 \mathrm{M}+\mathrm{Na}]^{+}, 381(100)\left[\mathrm{M}+\mathrm{H}-\mathrm{H}_{2} \mathrm{O}\right]^{+}$.

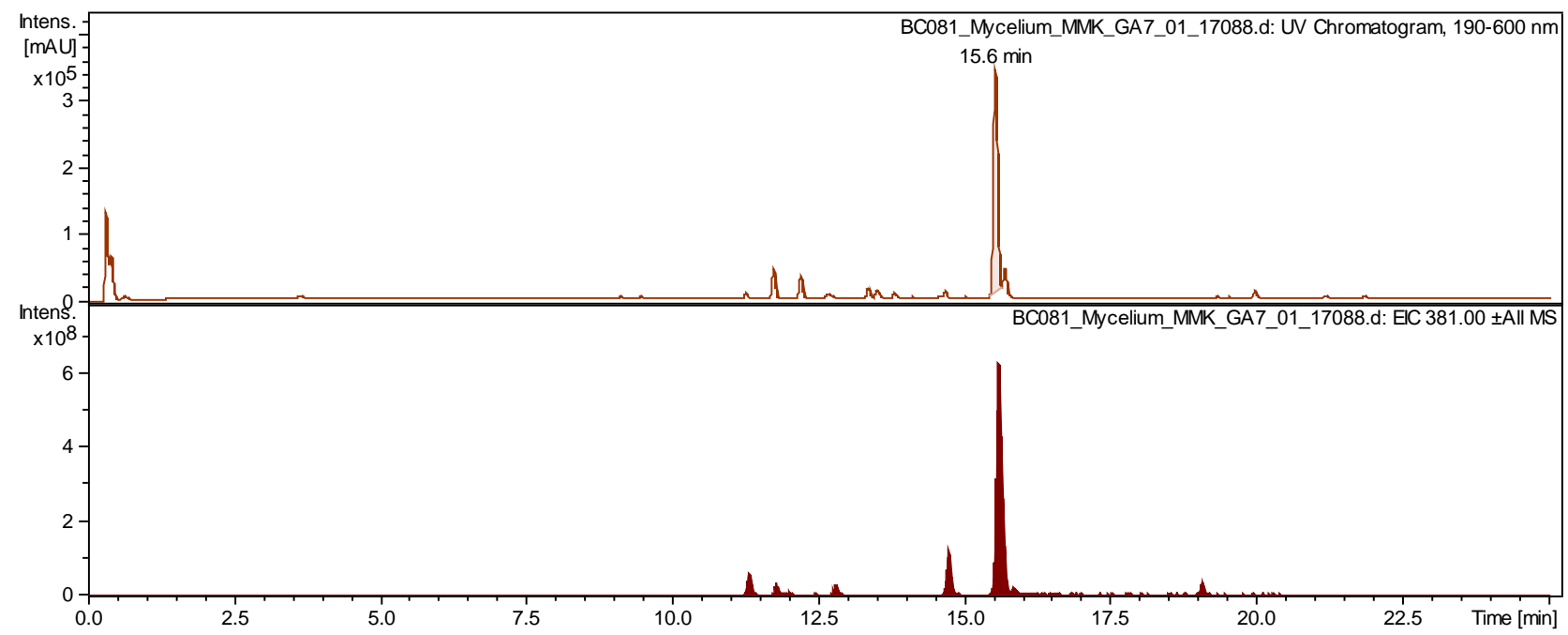

Fig. 1 - HPLC chromatogram of blazeispirol A (1) identified from the crude extract of $A$. flocculosipes (mycelium) cultivated in MMK-medium.

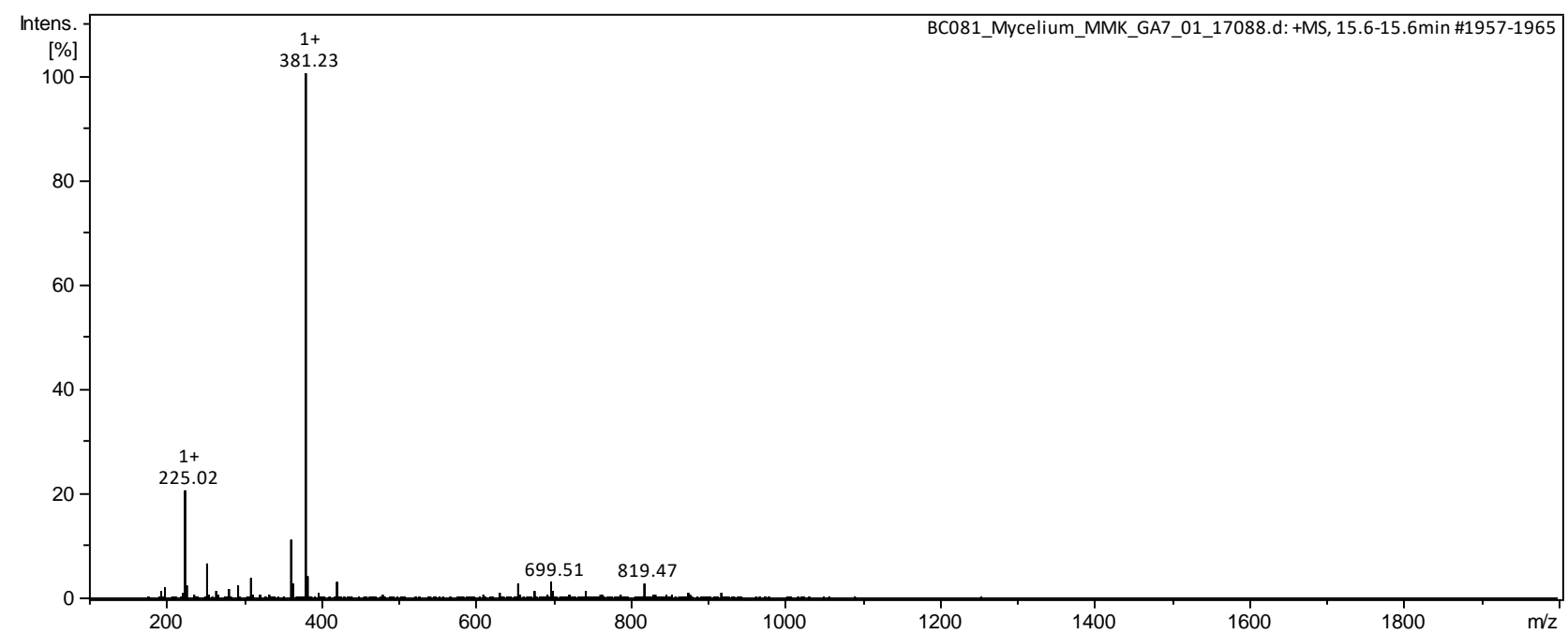

Fig. 2 - ESI-MS spectrum of blazeispirol A (1) identified from the crude extract of A. flocculosipes (mycelium) cultivated in MMK-medium. 


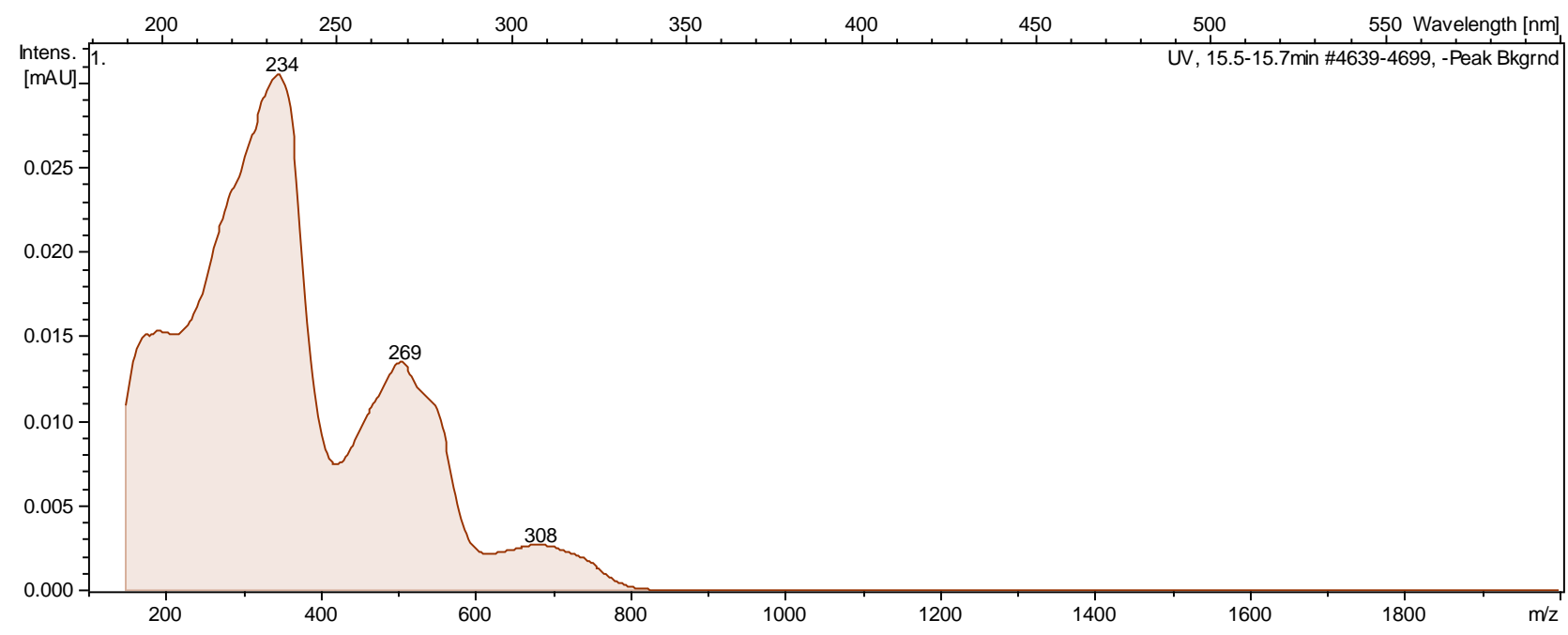

Fig. 3 - UV/Vis spectrum of blazeispirol A (1) identified from the crude extract of A. flocculosipes (mycelium) cultivated in MMK-medium.

Blazeispirol D (2): UV/Vis: $\lambda_{\text {qual }}=227,272,312 \mathrm{~nm}$; analytical HPLC $\left(t_{\mathrm{R}}\right)=12.70 \mathrm{~min}$; ESI $(+)$ MS: $m / z(\%)=367(100)\left[\mathrm{M}+\mathrm{H}-\mathrm{H}_{2} \mathrm{O}\right]^{+}$.

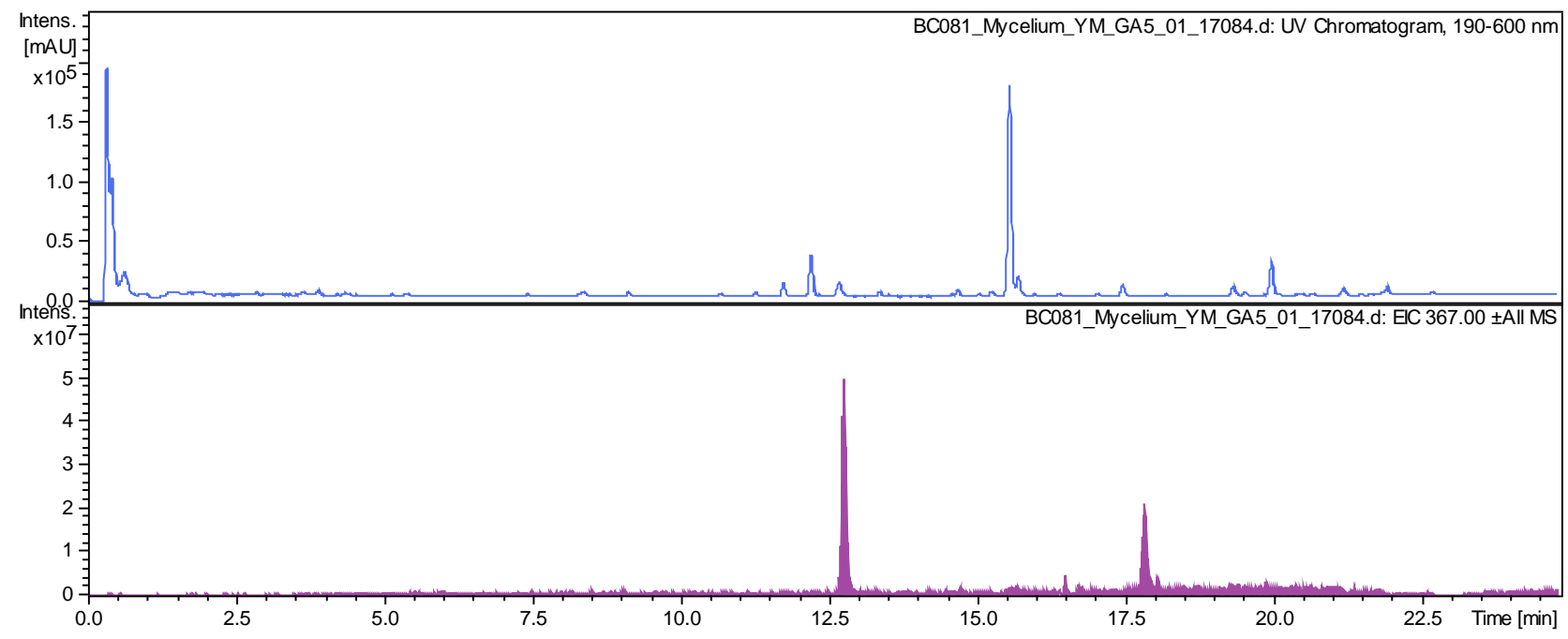

Fig. 4 - HPLC chromatogram of blazeispirol D (2) identified from the crude extract of $A$. flocculosipes (mycelium) cultivated in YM-medium. 


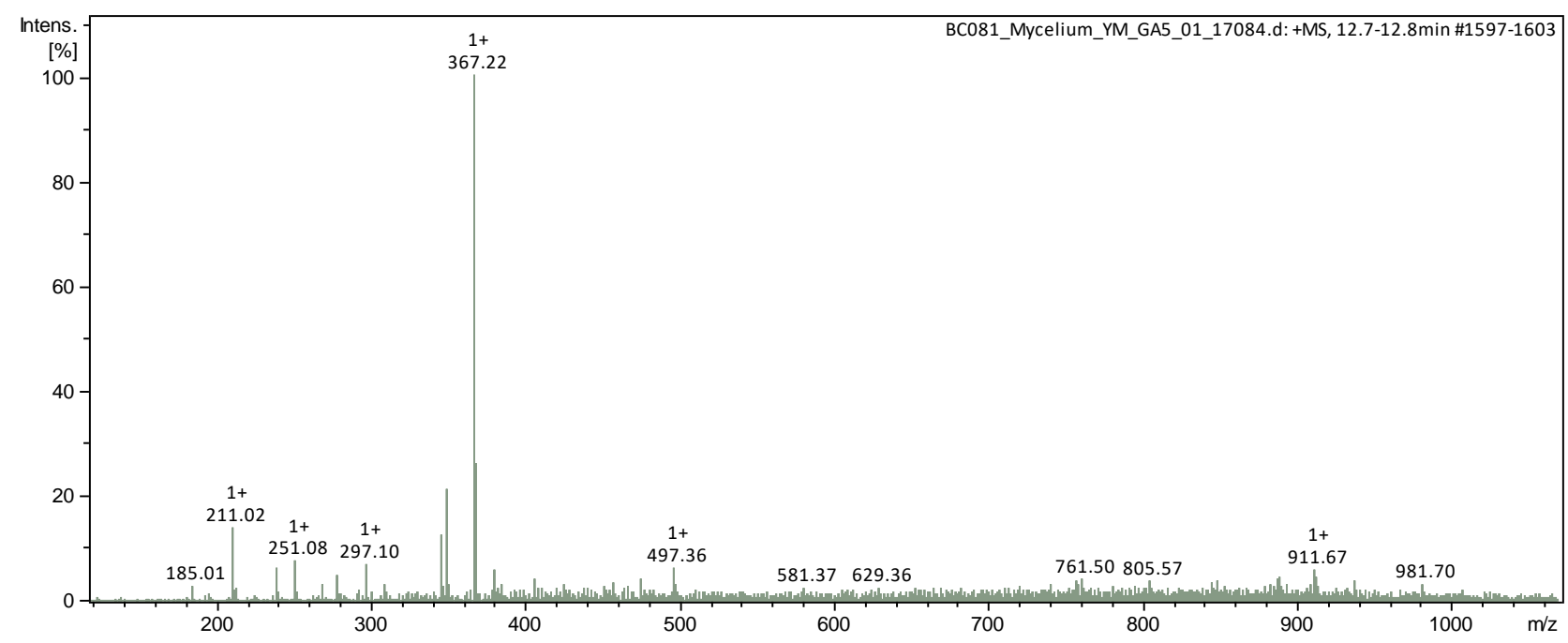

Fig. 5 - ESI-MS spectrum of blazeispirol D (2) identified from the crude extract of $A$. flocculosipes (mycelium) cultivated in YM-medium.

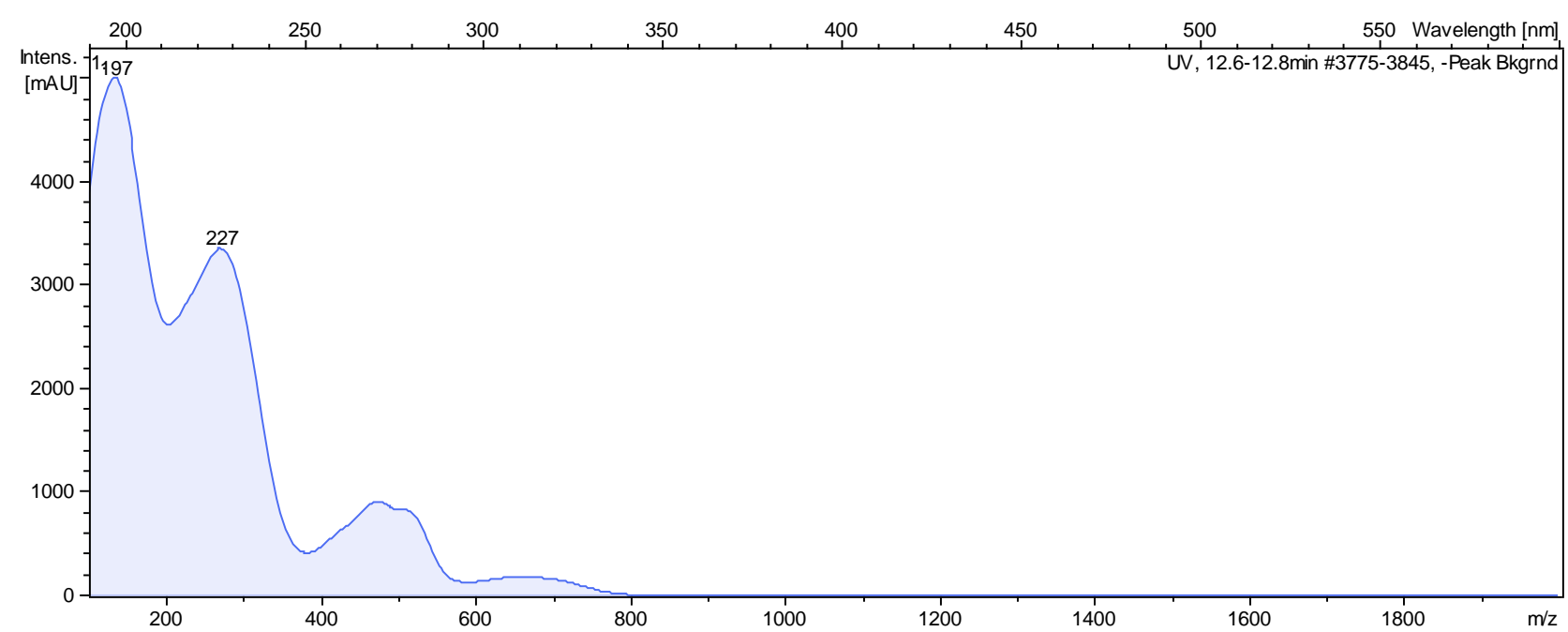

Fig. 6 - UV/Vis spectrum of blazeispirol D (2) identified from the crude extract of A. flocculosipes (mycelium) cultivated in YM-medium. 